\title{
HUBUNGAN ANTARA KEBIASAAN MENONTON FILM BERBAHASA INGGRIS MENGGUNAKAN ENGLISH SUBTITLE DAN KEMAMPUAN BERBICARA BAHASA INGGRIS
}

\author{
Megawati $^{1(*)}$, Eka Rista Harimurti ${ }^{2}$, Neng Nurwiatin ${ }^{3}$, Nurhasanah ${ }^{4}$ \\ STKIP Kusumanegara, Indonesia ${ }^{1-4}$ \\ megawati86@stkipkusumanegara.ac.id ${ }^{1}$, ekaristaharimurti@ stkipkusumanegara.ac.id ${ }^{2}$, \\ nengnurwiatin@yahoo.com ${ }^{3}$, nurhasanah@ @stkipkusumanegara.ac.id ${ }^{4}$
}

$\begin{array}{ll}\text { Received: } & 27 \text { Januari } 2021 \\ \text { Revised: } & 07 \text { Maret } 2021 \\ \text { Accepted: } & 21 \text { Agustus } 2021\end{array}$

\begin{abstract}
Kebiasaan menonton film berbahasa inggris menggunakan English Subtitle dapat mendorong mahasiswa memiliki kemampuan berbicara bahasa Inggris yang baik karena dalam berbicara dibutuhkan penguasaan kosakata serta susunan kata, frase, kalimat juga maksud yang disampaikan. Penelitian ini bertujuan untuk mengetahui hubungan antara kebiasaan menonton film berbahasa Inggris menggunakan English Subtitle dan kemampuan berbicara. Penelitian ini dilakukan pada mahasiswa semester tiga Prodi Pendidikan Bahasa Inggris STKIP Kusumanegara Jakarta. Metode Penelitian adalah kuantitatif dengan mengambil sampel berjumlah 20 mahasiswa. Data yang diambil berupa tes kemampuan berbicara dan kuesioner kebiasaan mahasiswa menonton film berbahasa Inggris menggunakan English subtitle. Penelitian ini menggunakan dua variable. Variabel bebas yaitu kebiasaan menonton film berbahasa Inggris menggunakan English subtitle dan variable terikat yaitu kemampuan berbicara bahasa Inggris. Hasil dari penelitian tersebut diperoleh sig. (2tailed) $0.014<0.05$ artinya kemampuan berbicara yang tinggi dipengaruhi oleh kebiasaan menonton film. Terdapat hubungan yang positif antara kebiasaan menonton film berbahasa Inggris dengan English subtitle dan kemampuan berbicara. Taraf koefisien korelasi $0.539>0.05$ Maksudnya yaitu apabila tingkat kebiasaan menonton film berbahasa Inggris tinggi maka kemampuan berbicara bahasa Inggris pun tinggi dan apabila tingkat kebiasaan menonton film barat rendah maka kemampuan berbicara bahasa Inggris pun rendah.
\end{abstract}

Keywords: Hubungan, Kebiasaan Menonton Film, Kemampuan Berbicara, Bahasa Inggris

(*) Corresponding Author: Megawati, megawati86@stkipkusumanegara.ac.id, +62 81285961641

How to Cite: Megawati, Harimurti, E. R., Nurwiatin, N., \& Nurhasanah. (2021). Hubungan Antara Kebiasaan Menonton Film Berbahasa Inggris Menggunakan English Subtitle Dan Kemampuan Berbicara Bahasa Inggris. Research and Development Journal of Education, 7 (2), 363-372.

\section{INTRODUCTION}

Perkembangan teknologi menuju era 5.0 sangat memberi pengaruh dan peranan besar pada berbagai lini kehidupan. Perubahan yang terjadi secara langsung maupun tidak langsung dapat memberi pengaruh besar pada merebaknya ilmu pengetahuan dan informasi yang tanpa memiliki batasan ruang dan waktu. Oleh karena itu, kesadaran individu dari berbagai generasi terhadap pentingnya mempersiapkan pengetahuan terhadap hal ini sungguh merupakan sesuatu yang harus dilakukan. Salah satu hal yang penting untuk dipersiapkan dalam menyongsong kemajuan teknologi dan informasi ini adalah kemampuan berbahasa Inggris yang baik dan benar, sesuai standar komunikasi dan pemahaman terhadap makna yang disampaikan dengan cara interaksi yang baik dan benar pula. Para generasi muda diharapkan dapat memiliki kesadaran dalam berbahasa 
Inggris yang baik karena kebutuhan akan perkembangan teknologi informasi 5.0 yang memungkinkan peranan bahasa Inggris dalam mengakses informasi dan penggunaanya yang semakin tinggi. Hal ini menjadi salah satu sebab bahwa penguasaan bahasa Inggris baik lisan maupun tulisan merupakan hal yang tidak dapat dipungkiri lagi, disamping itu mengingat bahwa bahasa Inggris merupakan salah satu bahasa Internasional yang penggunaanya sudah mendunia sehingga bukanlah suatu hal yang sulit menemukannya dalam keseharian aktifitas manusia saat ini, seperti banyaknya penggunaan kosakata bahasa Inggris dalam aplikasi belanja online, aplikasi yang bertemakan pendidikan, dalam informasi berita di televise, atau saluran hiburan musik, film dan talk show, dipapan informasi sekolah atau ditempat-tempat publik lainnya. Selain penggunaanya yang tertulis, bahasa dalam kosakata tersebut juga digunakan secara lisan pada situasi tertentu oleh beberapa masyarakat pengguna baikdi dunia online (dalam jaringan) mapupunoffline (luar jaringan). Dengan kesinambungan yang sejalan antara kemampuan bahasa inggris yang baik dan perkembangan teknologi dan informasi akan memudahkan generasi muda khususnya para generasi terdidik atau mahasiswa untuk mendapatkan pekerjaan yang layak, sehingga mereka pun tidak akan mengalami suatu ketertinggalan di masa yang akan datang.

Generasi muda yang tidak dapat mengikuti perkembangan teknologi maka akan tertinggal dan sulit untuk mendapatkan pekerjaan layak. Pembelajaran baik dibangku sekolah sampai perguruan tinggi secara online serta pekerjaan yang menggunakan kecanggihan teknologi. Pandemi Covid-19 saat ini secara instan meningkatkan interaksi individu dengan orang lain menjadi berbasis digital baik dalam kepentingan formal maupun tidak formal. Salah satunya adalah kegiatan belajar mengajar saat ini yang dilakukan secara non tatap muka dan tentunya membutuhkan peranan digital untuk mendukung tercapainya tujuan belajar mengajar. mahasiswa melaksanakan kegiatan pembelajaran secara online dengan media zoom, google classroom, edmodo ataupun sejenis LMS lainnya. Terdapat berbagai macam media pembelajaran yang digunakan dosen dengan tujuan memudahkan dalam menyampaikan materi. Pembelajaran secara online didukung dengan perangkat seperti laptop dan handphone serta jaringan yang baik. Berbagai aplikasi pembelajaran yang dalam penerapannya menggunakan bahasa inggris dan non bahasa Inggris dalam instruksinya, oleh karena itu pentingnya pemahaman berbahasa inggris. Apabila mahasiswa memiliki pemahaman bahasa Inggris yang baik maka akan mudah dalam menggunakannya.

Mahasiswa dapat memanfaatkan perkembangan teknologi dengan menggunakan media yang mudah dan sering digunakan dalam pembelajaran khususnya dalam mempelajari Bahasa Inggris sehingga lebih menyenangkan dan tidak membosankan. Saat ini banyak media yang dapat digunakan untuk meningkatkan kemampuan berbicara Bahasa Inggris seperti media music, video, film dan lain sebagainya, sebagaimana yang dikatakan oleh Wright (Wright, 2005) memanfaatkan teknologi di dalam pembelajaran telah mejadi topik yang paling banyak dibicarakan dalam lingkup pengajaran Bahasa sejak tahun 1920. Wright juga menjelaskan bahwa media audio visual sperti film, video atau DVD adalah media yang paling sering digunakan sebagai sumber pembelajaran sejak tahun 1970 dan telah banyak peneliti menegaskan pengaruh media tersebut bagi pembelajaran.

Film merupakan salah satu media audio visual yang dapat dengan mudah dijumpai dalam keseharian. Malley (J. Michael O'Malley \& Lorraine Valdez Pierce, 1991) mendefinisikan film sebagai media komunikasi yang komplet dan merupakan pengantar informasi yang sangat kuat. Film berisi pesan, gambar dan ambiguitas sehingga film merupakan suatu hal yang kaya untuk digunakan dalam pembelajaran Bahasa. Menonton film sudah menjadi kebiasaan atau kegemaran (hobi) hal ini dapat digunakan oleh pengajar Bahasa dengan menyajikan materi pembelajaran yang authentic. Koshinsky 
(Koshinsky, 2008) menyebutkan beberapa alasan guru dapat memanfaatkan film dalam kelas pembelajaran Bahasa. Yang pertama adalah karena film menyajikan hiburan dan pembelajaran dengan suatu cerita yang dapat merebut hati para penontonnya. Yang kedua adalah karena Bahasa lisan di dalam film didukung dengan elemen visual yang membuat siswa menjadi lebih mudah dalam memahami dialog dan jalan cerita. Yang ketiga adalah karena film dalam bentuk DVD biasanya menampilkan teks dalam Bahasa Inggris atau Bahasa Indonesia yang membantu siswa memahami dan mengembangkan kosakata dan kemampuan berbahasa Inggris lainnya seperti reading dan listening.

Kegiatan menonton film berbahasa Inggris tidak hanya dapat dilakukan untuk tujuan hiburan semata akan tetapi juga untuk tujuan yang lebih bermanfaat seperti memperkaya kosakata sehingga dapat meningkatkan kemampuan berbahsa Inggris. Blake (Blake, 1990) film berbahasa Inggris menunjukkan kepada siswa tentang Bahasa Inggris yang alami dan asli, meskipun hanya sedikit adegan yang digunakan. Blake menambahkan bahwa film ataupun adegan berbahasa Inggris merupakan sumber yang baik pada kegiatan vocabulary building, diskusi kelas, writing dan listening. Oleh karena itu, film merupakan salah satu media yang efektif dalam menunjukkan Bahasa asing kepada mahasiswa.

Menggunakan film sebagai media belajar Bahasa Inggris memberikan latar belakang informasi yang mengaktifkan prior knowledge pada mahasiswa yang sangat penting dalam menstimulasi ke-empat kemampuan berbahasa Herron dan Hanley dalam Canning (Canning-Wilson, n.d.) Kegiatan menonton film memberikan hiburan dan membuat mahasiswa tertarik dan menikmati belajar Bahasa Inggris. Film biasanya menampilkan audio dan visual dengan teks yang dapat membantu mahasiswa memahami makna dan ejaan kata-kata yang baru sehingga diharapkan melalui kegiatan menonton film dapat memperkaya kosa kata dan meningkatkan kemampuan berbahasa Inggris mahasiwa khususnya kemampuan bebicara (speaking).

Untuk mendukung kemampuan berbahasa Inggris yang baik, dosen meminta mahasiswa mengasah kemampuan berbicara bahasa Inggrisnya dengan membiasakan menonton film berbahasa Inggris yang menggunakan English Subtitle. Film dapat menjadi salah satu media atau sarana dalam pembelajaran. Menonton film merupakan suatu aktifitas yang dapat dilakukan siapapun mulai dari anak-anak, remaja, hingga orang dewasa. Film menjadi suatu kegemaran tersendiri bagi orang-orang yang hobi menonton film. Namun yang perlu digaris bawahi adalah penyampaian alur cerita dalam film yang dapat dijadikan pembelajaran berbicara / speaking adalah film berbahasa Inggris yang menggunakan English subtitle. Dengan menggunakan English subtitle maka diharapkan mahasiswa dapat mencari tahu arti dari istilah, kosakata, idiom yang di dengar dan dibaca melalui teks berjalan.

Dengan melihat tayangan film berbahasa Inggris menggunakan English subtitle, mahasiswa dapat melatih konsentrasi pendengaran. Berbagai kosakata bahasa Inggris dengan menggunakan aksen british ataupun American dapat di dengar. Berbagai ungkapan/ idiom, frase yang disampaikan aktor dan aktris dalam film tersebut akan menjadi bahan pembelajaran bagi mahasiswa. Mahasiswa dapat meniru ucapan yang ada dalam film berbahasa Inggris serta dapat memperkaya perbendaharaan kosakata. Menonton film merupakan suatu kebiasaan yang pada masa pandemi Covid-19 saat ini digemari baik mahasiswa, anak-anak ataupun orang tua dalam mengisi waktu senggang. Namun film yang berbahasa Inggris menggunakan English subtitle dapat menambah pemahaman dalam kemampuan bahasa Inggris. Berbagai kosakata yang didengar mahasiswa kemudian diolah untuk menjadi kalimat, frase, idiom / ungkapan, istilah yang dapat diucapkan mahasiswa serta memiliki makna. Hal yang disampaikan mahasiswa tersebut dapat dipahami oleh orang lain, sehingga proses komunikasi terjadi. Menurut Jeihan (2019: 174) pengusaan kosakata yang baik dapat mendukung kemampuan 
berbahasa Inggris seseorang. Kosakata menjadi salah satu pendukung dalam elemen atau unsur berbicara. Apabila seseorang yang ingin berbicara bahasa asing missal bahasa Inggris, memahami makna kosakata, maka orang tersebut akan dengan mudah berbicara menggunakan bahasa Inggris.

Dalam penelitian ini, peneliti ingin mengetahui seberapa besar hubungan antara kebiasaan menonton film berbahasa Inggris menggunakan English Subtitle dan kemampuan berbicara bahasa Inggris. Apakah ada kaitan kebiasaan menonton film berbahasa Inggris dan kemampuan berbicara bahasa Inggris. Apakah mahasiswa yang terbiasa menonton film berbahasa Inggris memiliki keterampilan berbicara lebih tinggi daripada mahasiswa yang tidak gemar menonton film berbahasa Inggris. Apakah kebiasaan menonton film berbahasa Inggris memberikan efek yang positif terutama bagi mahasiswa/ pembelajar bahasa Inggris. Mahasiswa dapat mengucapkan kata atau kalimat berbahasa Inggris seperti native speaker. Mereka dapat dengan fasih melafalkan kata serta percaya diri ketika berbicara bahasa Inggris. Film dengan subtitle bahasa Inggris dapat menjadi sebuah media bagi mahasiswa dalam pembelajaran speaking / berbicara. Film bisa menjadi daya tarik tersendiri bagi mahasiswa yang malas belajar speaking. Menurut Megawati (2017: 108) Media merupakan salah satu komponen komunikasi yaitu sebagai pembawa pesan dari komunikan ke komunikator. Di saat pandemik Covid-19 saat ini, mahasiswa melakukan pembelajaran dengan berbagai media. Dalam film terdapat aktor dan aktris yang di dalamnya menyajikan dialog serta jalan cerita yang memiliki alur, mulai dari perkenalan, masalah yang timbul, pemecahan masalah serta penyelesaian. Mahasiswa belajar berbicara dari kata, kalimat yang ditampilkan dalam sebuah film. Berbagai ujaran serta, dialek yang muncul dapat menjadikan mahasiswa memiliki perbendaharaan kosakata yang baru. Menonton film tidak hanya sekedar menjadi hiburan tetapi lebih dari itu dapat menjadikan pembelajaran bahasa Inggris.

Menurut Hornby (1995:34) movie is a story, recorded as a set of morning pictures to be shown on television or at the cinema. Film adalah sebuah cerita yang diatur sedemikian rupa beralur dengan ditampilkan melalui sebuah tayangan bergambar pada sebuah televisi atau bioskop. Menurut Megawati (2017: 109) film merupakan media yang menyajikan pesan audiovisual dan gerak sehingga memberikan kesan yang impresif dan atraktif bagi penikmatnya. Media film merupakan media audio visual yang memiliki keindahan gambar bergerak yang dapat dilihat serta suara yang dapat di dengar. Mulyadi (2015:143) film Inggris mempunyai nilai moral pendidikan yang memotivasi serta menghibur terutama dalam menguasai kemampuan mendengar penutur asli. Ketika mahasiswa menonton film barat, mereka berlatih mendengar kosakata yang diucapkan kemudian mereka menangkap maksud dan artinya, pemahaman kosakata yang baik menjadikan mahasiswa memiliki keterampilan berbicara bahasa Inggris yang baik pula.

Menurut Dewi (2019:963) film merupakan media audio visual yang memiliki keindahan efek suara suara dan gambar. Efek suara dan gambar tersebut menjadikan mahasiswa tertarik untuk melihat yang kemudian menghafal kosakata yang tidak dipahami. Dengan memiliki perbendaharaan kosakata yang banyak maka mahasiswa akan dengan lebih mudah berkomunikasi dengan menggunakan bahasa Inggris. Menurut Napikul (2018:104) subtitle film dapat meningkatkan pembelajar bahasa asing, film dapat membantu mahasiswa dalam memahami karakter yang dibawakan selama percakapn berlangsung dalam film tersebut.

Berbicara merupakan salah satu kemampuan dasar dalam bahasa Inggris. Berbicara berarti memproduksi ucapan atau ujaran dengan perkataan secara lisan. Ucapan yang diproduksi berasal dari pemahaman akan suatu hal yang diterima dari luar sehingga dapat dismpaikan kepada orang lain. Kemampuan berbicara seseorang berkembang sejak dilahirkan yang semula hanya dapat mengucapkan huruf vokal kemudian huruf konsonan 
lalu kata dan terus berkembang hingga dewasa. Selain kemampuan dasar tersebut terdapat kemampuan yang lain seperti mendengarkan, menulis, dan membaca.

Kemampuan berbicara perlu dipelajari secara serius agar mendapatkan hasil yang maksimal. Menurut Bjorklund (2005) dalam perkembangan bahasa berkaitan dengan perkembangan berbicara. Apabila seorang anak memiliki perkembangan berbicara yang baik maka perkembangan bahasanya pun baik begitu pula sebaliknya. Perkembangan bahasa terjadi pada masa prasekolah, anak telah memiliki pemahaman bahasa yang berasal dari ibu, kemudian anak ketika masuk jenjang bangku sekolah belajar bahasa nasional yaitu bahasa Indonesia. Selain bahasa Indonesia, bahasa asing salah satunya adalah bahasa Inggris dipelajari sejak duduk dibangku sekolah dasar. Kata speaking berasal dari kata speak yaitu to express opinion; to say; to converse. Speaking atau berbicara memiliki cakupan yang luas, yang berarti mengeluarkan pendapat kepada orang lain. Kemudian orang lain tersebut menyimak apa yang kita bicarakan kemudian memberikan umpan balik. Dalam pembelajaran bahasa asing dibutuhkan kesadaran diri bagi para mahasiswa untuk dapat menerima kosakata baru serta mengingatnya kemudikan mempraktekan berbicara di depan orang lain. Dibutuhkan keberanian dan kepercayaan diri dalam diri mahasiswa untuk mempraktekan berbicara bahasa Inggris. Disinilah dosen berperan bagaimana caranya agar lingkungan English daily dapat terbagun. Bahasa yang pertama di dapatkan mahasiswa ketika lahir adalah bahasa ibu, kemudian bahasa yang diperoleh dengan usaha belajar merupakan bahasa asing. Bahasa Inggris adalah salah satunya.

Menurut Megawati (2019: 118) Speaking is the performance skills in English. When students learn English, they have to practice and also produce words, sentence by speech. Berbicara merupakan suatu keahlian yang dapat dilihat, ketika mahasiswa mempelajari bahasa Inggris, maka mereka dapat mempraktekannya serta mengasilkan kata, kalimat dengan ucapan. Berbicara merupakan suatu kemampuan yang terlihat, maksudnya adalah kemampuan yang dapat dilihat oleh orang lain ketika berbicara. Menurut Megawati (2018:17) By speaking students can communicate and interaction with other people. The students can utterance their feeling, idea, and giving opinion. Mahasiswa yang memiliki kemampuan berbicara maka mereka akan dapat berkomunikasi dan berinteraksi dengan yang lain, selain itu dapat melakukan ujaran yang artinya mahasiswa dapat menuangkan perasaan, ide pemikiran serta memberikan pendapat atau opini atas hal yang mereka pahami. Kemampuan berbicara yang baik bisa diperoleh apabila mahasiswa memiliki kemampuan kosakata yang baik. Selain itu pemahaman dalam penggunaan grammar juga diperlukan dalam berbahasa inggris. Agar pendengar atau orang yang diajak bicara dapat memahami kapan kejadian terjadinya, apakah baru selesai terjadi atau kah masih berlangsung.

Scott Thombury (2005:1) mengatakan Speaking is so much a part of daily life that we take it for granted. The average person procedures tens of thousands of words a day, although some people-like auctioneers and politicians-may produce even more than so natural integral is speaking that we forget how we once struggled to achieve this skilluntil, that is, we have to learn how to do it all over again in a foreign languages. Berbicara merupakan bagian dari kegiatan seharti-hari. Setiap orang dapat mengolah ribuan kata perhari untuk dapat berbicara baik bahasa yang digunakan sehari-hari atau bahasa asing yang perlu dipelajari.

Menurut Kitakagi (2013) seseorang yang mengingat kalimat bahasa Inggris memiliki efek dalam kemampuan berbicaranya, yang artinya menghafal memiliki peran dalam memproduksi bahasa secara lisan. Ketika berbicara bahasa inggris dibutuhkan beberapa kriteria sehingga mudah dipahami orang lain. Kriteria atau elemen tersebut yang menjadikan pembicara memiliki kemampuan berbicara yang baik. Menurut Brown (2004:172) elemen atau unsur berbicara dibagi menjadi beberapa aspek sebagai berikut : 
1. Grammar yang berarti kemampuan mahasiswa dalam memahami native speaker atau pembicara asal yang menggunakan bahasa inggris dalam berbicara

2. Vocabulary yang berarti pemahaman kosakata atau istilah-istilah dalam berbicara

3. Comprehension yang artinya memahami sebuah pertanyaan singkat, pernyataan, penyampaian sebuah ucapan, pengulangan serta mengerti dengan paraphrase

4. Fluency yang artinya kecakapan dalan berbicara seperti pembicara asli

5. Pronunciation yang artinya aksen atau dialek yang diucapkan

Apabila kelima elemen unsur dalam kemampuan berbicara tersebut terpenuhi maka mahasiswa telah memiliki kemampuan berbicara yang baik. Menurut Hanafiah (2019: 151) Proses pembelajaran bahasa asing terutama bahasa Inggris menuntut mahasiswa memiliki pengetahuan kosakata, pemahaman tata bahasa, semantik dan pragmatik. Beberapa hal tersebut merupakan unsur pendukung dalam kemampuan berbicara agar memperoleh kemampuan berbicara yang baik.

\section{METHODS}

Metode dalam penelitian ini adalah survey. Survey yang dilakukan adalah untuk mengetahui sejauh mana hubungan antara kebiasaan menonton film berbahasa Inggris dengan kemampuan berbicara. Menurut Frankel and Wallen (2008:328) Correlation research is a study to determine the relationship and the level of the relationship between two or ore variable without any attempt to influence the variable. Penelitian korelasi adalah sebuah penelitianuntuk menentukan, mengetahui apakah ada hubungan dan seberapa besar hubungan diantara dua variabel atau lebih tanpa adanya pengaruh antar variabel.

Penelitian ini merupakan kuantitatif menggunakan dua kelas mahasiswa semester tiga Prodi Pendidikan Bahasa Inggris katakan kelas A dan kelas B yang diambil sampel secara acak sebanyak 20 orang. Menurut Frankle dan Norman (2003: 97) menjelaskan sampling refers to the process of selecting individuals. Peneliti menggunakan mahasiswa semester tiga karena diharapkan mereka telah memiliki kemampuan berbicara bahasa Inggris yang baik, selain itu mereka telah mendapatkan mata kuliah Speaking sejak semester satu. Penelitian ini menggunakan dua variable, variable dependen dan variable independen. Variabel independent adalah kebiasaan mahasiswa menonton film berbahasa Inggris menggunakan English Subtitle dan variable dependen adalah kemampuan berbiacara. Instrument yang digunakan adalah angket dan test. Angket berupa kuesioner. Kuesioner menggunakan skala likert. Kuesioner berupa kebiasaan menonton film berbahasa Inggris menggunakan English subtitle. Test berupa speaking skill. Kuesioner yang diberikan sebanyak 20 pertanyaan yang setiap pertanyaan memiliki jawaban A, B, C dan $\mathrm{D}$, dimana jawaban A yang berarti selalu, B yang berarti sering, $\mathrm{C}$ yang berarti kadang-kadang dan D yang berarti tidak pernah.

Peneliti memberikan kuesioner kepada mahasiswa serta test kemampuan berbicara bahasa Inggris / speaking skill. Kemudian peneliti memeriksa hasil kuesioner dan hasil test kemampuan berbicara. Kuesioner yang diberikan disesuaikan dengan rubrik kebiasaan menonton film berbahasa Inggris menggunakan English subtitle. Test kemampuan berbicara disesuaikan dengan indikator penilaian Speaking skill. Setelah mendapat hasilnya peneliti menganalisis data yang didapat dengan program SPSS untuk mengetahui adakah hubungan kebiasaan menonton film berbahasa Inggris dengan kemampuan berbicara.

Koefisien korelasi menunjukkan hubungan antara kedua variable apakah memiliki hubungan yang positif atau negative. Hubungan kedua variable yang kuat dapat digambarkan dengan (+) atau (-). Apabila kedua variabel tidak memiliki hubungan maka 
koefisien korelasi adalah (0). Metode yang digunakan dalam penelitian adalah metode penelitian korelasi, metode tersebut dipilih untuk mengetahui sejauh mana hubungan antara dua atau lebih variable berdasarkan koefisien korelasi (correlation coefficient). Koefisien korelasi adalah suatu indeks yang membrikan informasi mengenai kekuatandan arah hubungan antara dua variabel atau lebih dengan koefisien korelasi -1,00 sampai dengan 0 sampai $+1,00$. Apabila nilai korelasi semakin besar maka hubungannya pun semakin kuat menurut Wiersma (2000:331). Positif korelasi apabila kedua variabel meningkat atau menurun secara bersamaan. Koefisien korelasi mendekati +1.00 yang mengindikasikan koefisien korelasi sangat kuat. Sedangkan yang dinamakan negative korelasi apabila salah satu variabel meningkat dan variabel yang satunya menurun. Koefisien korelasi mendekati -1.00 menunjukkan korelasi negatif.

\section{RESULTS \& DISCUSSION}

\section{Results}

Dalam test berbicara / speaking, mahasiswa diberikan waktu 7-10 menit untuk menjelaskan tempat objek wisata secara lisan. Dalam test berbicara mahasiswa diberikan arahan bahwa terdapat lima unsur / elemen yang perlu diperhatikan agar mendapatkan hasil yang maksimal. Kemudian diberikan kuesioner yang berkaitan dengan kebiasaan menonton film berbahasa Inggris menggunakan English Subtitle.

Pada tabel dibawah terdapat nilai atau skor minimum mahasiswa adalah 65 untuk tes berbicara dan skor maksimum adalah 86. Sedangkan untuk kebiasaan menonton film berbahasa Inggris dengan skor minimum adalah 30 dan skor maksimum adalah 47.

\section{Descriptive Statistics}

\begin{tabular}{|l|r|r|r|r|r|}
\hline & \multicolumn{1}{|c|}{ N } & Minimum & Maximum & \multicolumn{1}{c|}{ Mean } & Std. Deviation \\
\hline $\begin{array}{l}\text { Kebiasaan menonton film } \\
\text { berbahasa Inggris }\end{array}$ & 20 & 30 & 47 & 37.20 & 4.641 \\
Kemampuan Berbicara & 20 & 65 & 86 & 77.95 & 6.168 \\
Valid N (listwise) & 20 & & & & \\
\hline
\end{tabular}

Gambar 1.

Deskriptif Statistik

Sumber: Data diolah Peneliti (2021)

Berdasarkan tabel diatas, dapat dilihat bahwa nilai rata-rata kemampuan berbicara adalah 77.95, mahasiswa dengan nilai tertinggi 86 dan nilai terendah 65 dengan standar deviasi adalah 6.168 dan rata-rata kebiasaan menonton film berbahasa Inggris adalah 37.20 dengan standar deviasi adalah 4.641. $\mathrm{N}$ adalah jumlah sampel sebanyak 20 mahasiswa. Diketahui hubungan antara ketertarikan mahasiswa terhadap kemampuan berbicara dengan nilai Sig. (2-tailed) $>0.05$; yang berarti hypothesis awal diterima. Maksudnya adalah bahwa data berdistribusi normal. 
One-Sample Kolmogorov-Smirnov Test

\begin{tabular}{|c|c|c|c|}
\hline & & $\begin{array}{l}\text { Kebiasaan } \\
\text { menonton } \\
\text { film } \\
\text { berbahasa } \\
\text { Inggris }\end{array}$ & $\begin{array}{c}\text { Kemampuan } \\
\text { Berbicara }\end{array}$ \\
\hline$N$ & & 20 & 20 \\
\hline \multirow[t]{2}{*}{ Normal Parameters ${ }^{a, b}$} & Mean & 37.20 & 77.95 \\
\hline & Std. Deviation & 4.641 & 6.168 \\
\hline \multirow[t]{3}{*}{ Most Extreme Differences } & Absolute & .182 & .144 \\
\hline & Positive & .182 & .096 \\
\hline & Negative & -.094 & -.144 \\
\hline Kolmogorov-Smirnov Z & & .815 & .642 \\
\hline Asymp. Sig. (2-tailed) & & .520 & .805 \\
\hline
\end{tabular}

a. Test distribution is Normal.

b. Calculated from data.

Gambar 2.

Normalitas data

Sumber: Data diolah Peneliti (2021)

\section{Discussion}

Setelah melakukan uji normalitas, peneliti melanjutkan dengan mencari hubungan antara kebiasaan menonton film berbahasa Inggris menggunakan English Subtitile dan kemampuan berbicarabahasa Inggris mahasiswa.

Correlations

\begin{tabular}{|ll|r|r|}
\hline & & $\begin{array}{c}\text { Kebiasaan } \\
\text { menonton } \\
\text { film } \\
\text { berbahasa } \\
\text { Inggris }\end{array}$ & $\begin{array}{c}\text { Kemampuan } \\
\text { Berbicara }\end{array}$ \\
\hline $\begin{array}{l}\text { Kebiasaan menonton film } \\
\text { berbahasa Inggris }\end{array}$ & Pearson Correlation & 1 & $.539^{*}$ \\
& Sig. (2-tailed) & 20 & .014 \\
\hline Kemampuan Berbicara & Pearson Correlation & $.539^{*}$ & 20 \\
& Sig. (2-tailed) & .014 & 1 \\
& $\mathrm{~N}$ & 20 & 20 \\
\hline
\end{tabular}

*. Correlation is significant at the 0.05 level (2-tailed).

\section{Gambar 3.}

Hubungan kebiasaan menonton film berbahasa Inggris menggunakan English Subtitle dan kemampuan berbicara bahasa Inggris

Berdasar tabel diatas, dapat terlihat bahwa koefisien korelasi untuk kebiasaan mahasiswa menonton film berbahasa inggris menggunakan English subtitle adalah 0.539, ini yang berarti Pearson Product Momen koefisien korelasi adalah (+) positive korelasi antara kebiasaan menonton film berbahasa Inggris menggunakan English Subtitle dan kemampuan berbicara bahasa Inggris. Kemudian pada tabel terlihat skor signifikan adalah 0.014 dengan kata lain $(\mathrm{Ha})$ diterima dan $\left(\mathrm{H}_{0}\right)$ ditolak. 
Jika Sig (2-tailed) adalah $>0.05$, yang berarti tidak ada hubungan atau korelasi Jika Sig (2-tailed) adalah $<0.05$, yang berarti korelasi signifikan

Terdapat dua hypothesis dalam penelitian tersebut. Yang pertama $\mathrm{H}_{0}$ yang berarti tidak ada korelasi antara kebiasaan menonton film berbahasa Inggris menggunakan English subtitle dengan kemampuan berbicara bahasa inggris. Yang kedua Ha berarti terdapat korelasi positif anatara kebiasaan menonton film berbahasa Inggris menggunakan English subtitle dengan kemampuan berbicara bahasa Inggris. Jika Sig. (2-tailed) adalah $0.014<0.05$, yang berarti terdapat hubungan antara kebiasaan menonton film berbahasa Inggris menggunakan English Subtitle dan kemampuan berbicara bahasa Inggris.

Tujuan dalam penelitian ini adalah menentukan apakah ada hubungan antara kebiasaan menonton film berbahasa Inggris dengan English subtitile dan kemampuan berbicara. Hasil dari penelitian adalah terdapat hubungan yang positif antara kebiasaan mahasiswa dengan kemampuan berbicara dengan koefisien korelasi $0.014<0.05$. Tanda positive (+) menunjukkan bahwa semakin tinggi kebiasaan mahasiswa menonton film berbahasa Inggris dengan English subtitle maka semakin besar nilai kemampuan berbicara bahasa Inggrisnya.

\section{CONCLUSION}

Film berbahasa Inggris dengan English Subtitle memiliki daya tarik tersendiri bagi mahasiswa dalam belajar bahasa Inggris terutama speaking. Ketika mahasiswa menonton film berbahasa Inggris tetapi tidak tahu apa yang dibicarakan aktor/aktris dalam jalan cerita film tersebut, maka mereka akan mencari tahu arti atau makna melalui teks berbahasa Inggris yang ditampilkan. Mahasiswa akan mengartikan kata dan frase yang sulit kedalam bahasa Indonesia. Kesulitan mahasiswa untuk memahami kosakata akan menghambat mereka dalam memiliki kemampuan berbicara bahasa Inggris. Mahasiswa yang terbiasa dengan menonton film berbahasa Inggris cenderung memiliki kemampuan komunikasi dalam bahasa inggris yang baik. Mereka akan banyak mengetahui dan memahami berbagai kosakata serta dapat melafalkan kata-kata sesuai dengan native speaker. Dalam penelitian tersebut di dapatkan hasil terdapat hubungan yang positif koefisien korelasi antara kebiasaan mahasiswa menonton film berbahasa Inggris menggunakan English Subtitle dan kemampuan berbicara bahasa Inggris mahasiswa. Mahasiswa yang memiliki kebiasaan menonton film berbahasa Inggris menggunakan English Subtitle maka mereka akan memiliki kemampuan berbicara yang tinggi pula. Mahasiswa yang memahami makna serta tulisan dari pelafalan bahasa Inggris maka mereka akan tumbuh rasa percaya diri ketika berbicara menggunakan bahasa Inggris.

\section{REFERENCES}

Bjorklund, David F. (2005). Children's Thinking: Cognitive Development and Individual Differences. Australia:Wadsworth.

Blake, B. (1990). Relational Grammar (1st ed.). Taylor \& Francis.

Brewster, J., Ellis, G., \&Girrard, D. (1992). The Primary English Teacher's Guide. Penguin English.

Burns, R.B. (2000). Introduction To Research Methods: $4^{\text {th }}$ Edition. New South Wales: Longman

Canning-Wilson, C. (n.d.). Practical Aspects of Using Video in the Foreign Language 
Classroom. The Internet TESL Journal. http://iteslj.org/

Dzanic, Nihada Delibegovic and Alisa Peijic. (2016). The Effect of Using Songs on Young Learners and Their Motivation For Learning English. NETSOL An interdisciplinary Journal Volume 1, issue 2, October 2016, pp 40-54 https://www.researchgate.net/publication/312054146

Fraenkel Jack R, and E. Wallen Norman. (2012). How to Design and Evaluate Research Education $8^{\text {th }}$ Edition. New York: Mc Graw Hill

Griffe, D.T. (1990). Hey Baby! Teaching Short and Slow Songs in the ESL Classroom. TESLRepoter 23 (4): 64-72

Hanafiah, Wardah. (2019). Peningkatan Keterampilan Berbicara Bahasa Inggris melalui Media Film. Jurnal Epigram, Vol. 16 No. 2 Oktober 2019

Harmer, J. (2007). How to Teach English. Harlow: Longman.

Hornby, A.S. (1995). Oxford learner's Dictionary of Current English. London: Oxford University Press

Ifadah, uthimatul dan Siti Aimah. (2012). Kefektifan lagu sebagai media belajar dalam Pengajaran Pronunciation/Pengucapan. Seminar Hasil-Hasil Penelitian-LPPM UNIMUS 2012. ISBN : 978-60218809-0-6. http:/jurnal.unimus.ac.id

J. Michael O'Malley, \& Lorraine Valdez Pierce. (1991). Authentic Assessment for English Language Learners: Practical Approaches for Teachers. Pearson Education ESL.

Jeihan, Cherissa dan Kadek Oktarina Wirottami. (2019). Studi Korelasi Antara Kebiasaan Menonton Film Berbahasa Inggris, Penguasaan Kosakata, dan Kemampuan Menulis Bahasa Inggris. Jurnal ilmiah Pendidikan. ISSN: 2354-5968 hal 173

Kitagaki, I (2013). Effect of English Sentences Memorization on the Speaking Skill and the E-learning of English. Procedia-Social and Behavioral Sciences, 103,348351.https://doi.org/10.1016/J.SBSPRO.2013.10.343

Koshinsky, E. (2008). How to teach speaking.

Megawati, M. (2017). Pengaruh Media Poster terhadap Hasil Belajar Kosakata Bahasa Inggris (Eksperimen di Sdit Amal Mulia Tapos Kota Depok). Getsempena English Education Journal, 4(2), 217637.

Megawati, M. (2018). Improving The Studentsâ€TM Speaking Skill Through Storytelling Technique Toward Eleventh Grade Students At SMK Swasta Cimanggis. BRIGHT: A Journal of English Language Teaching, Linguistics and Literature, 2(1).

Megawati. (2019). The Correlation Between Students'Anxiety and Speaking Skill at STKIP Kusuma Negara Jakarta (A survey Research First Semester Academic Year 2018/2019). Scope: Journal of English Language Teaching Volume 03, Issue 02, March 2019.

Mulyadi, Dodi \& Yulia Mutmainnah. (2015). Penggunaan Film Berbahasa Inggris Dengan English Subtitle Dalam Meningkatkan Keterampilan Listening. The $2^{\text {nd }}$ University Research Coloquium 2015. ISSN 2407-9189

Napikul, S. (2018). The effects of Film Subtitles on English Listening Comprehension and Vocabulary. International Journal of Applied \& English Literature. p. 104

Nurmala, Dewi. (2019). Media Film Berbahasa Inggris Dalam Pembelajaran Listening. Prosiding Seminar Nasional \& Expo II Hasil Penenlitian dan Pengabdian Masyarakat 2019. hal 963-968

Thomburry, Scott. (2005). How To Teach English.

Wiersma. (2000). Metode Statistika. Badung: Tarsito

Wright, J. A. (2005). Animation Writing and Development (First). Focal Press. 